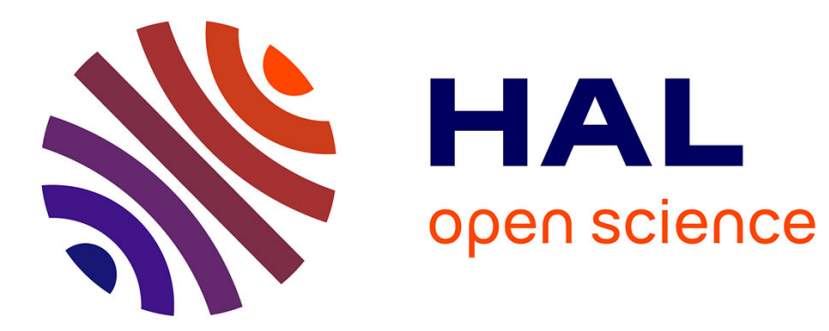

\title{
Optimization of a rear system based on titanium nitride for a flexible CuInSe2 solar cell
}

B.E. Messaid, C.L. Paven, R.Z. Talaighil, R. Benzerga, L.L. Gendre, Florent Marlec, F. Bensouici

\section{- To cite this version:}

B.E. Messaid, C.L. Paven, R.Z. Talaighil, R. Benzerga, L.L. Gendre, et al.. Optimization of a rear system based on titanium nitride for a flexible CuInSe2 solar cell. Optik, 2020, 206, pp.164305. 10.1016/j.ijleo.2020.164305 . hal-02499780

\section{HAL Id: hal-02499780}

\section{https://hal-univ-rennes1.archives-ouvertes.fr/hal-02499780}

Submitted on 1 Apr 2020

HAL is a multi-disciplinary open access archive for the deposit and dissemination of scientific research documents, whether they are published or not. The documents may come from teaching and research institutions in France or abroad, or from public or private research centers.
L'archive ouverte pluridisciplinaire HAL, est destinée au dépôt et à la diffusion de documents scientifiques de niveau recherche, publiés ou non, émanant des établissements d'enseignement et de recherche français ou étrangers, des laboratoires publics ou privés. 


\title{
Optimization of a rear system based on Titanium Nitride for a
}

\section{flexible CuInSe2 solar cell}

Bachir Eddine Messaid ${ }^{1,2}$, Claire Le Paven², Razika Zair Talaighil ${ }^{1,3}$, Ratiba Benzerga ${ }^{2}$, Laurent Le Gendre $^{2}$, Florent Marlec ${ }^{2}$, Faycal Bensouici ${ }^{1}$

1. advanced materials by Sol-Gel, Research unit of materials processes and environment (URMPE ),University M'hamed Bougara of Boumerdes 35000 ,Algeria

2. FunMAT team, Electronics and Telecommunications Institute of Rennes (IETR), University of Rennes, France

3. Institute of Electrical \& Electronic Engineering, University M'hamed Bougara of Boumerdes, 35000,Algeria

\section{Highlights}

- Much less expensive method was adopted to deposit the absorbent layer $\mathrm{CuInSe} 2$.

- The good crystallization of CISe deposited on glass requires a deposition temperature of $550^{\circ} \mathrm{C}$. the gap value is in good agreement with the literature.

- The CISe layers deposited on stainless steel 316 exhibits a bad crystallization and stoichiometry.

- -The high deposition temperature of CISe promotes the diffusion of metallic impurities from stainless steel 316 to the absorbent layer.

- $\quad$ The TiN / Ti bilayer was investigated on the stainless steel 316 substrate at an ambient temperature.

- The TiN / Ti bilayer improves the surface condition of the stainless steel substrate.

- $\quad$ The TiN / Ti decrease the diffusion of iron from $9.7 \%$ at. to $1.9 \%$ at. and $\mathrm{Cr}$ from 3.8 to $0.5 \%$ at.

\begin{abstract}
Flexible thin film solar cells represent the future. This study concentrates on making CuInSe 2 based solar cells non rigid by depositing the rear molybdenum contact onto inox 316 .
\end{abstract}


In order to overcome the Inox316 disadvantages such as the metallic impurities diffusion and the surface roughness, a bi-layer TiN/Ti have been introduced between the Mo rear contact and Inox 316. Two techniques have been employed: spray pyrolysis for $\mathrm{CuInSe}_{2}$ and by cathodic magnetron sputtering for Mo/TiN/Ti. CuInSe 2 layers deposited onto glass substrates present high crystallinity with (112) preferred orientation at $550^{\circ} \mathrm{C}$. However, these properties disappear for $\mathrm{CuInSe}_{2}$ on Inox316 with missing peak (112) and fall in the ratio $\mathrm{Se} / \mathrm{Cu}$ from 1.9 to 1.1 .

According to EDS analysis, these results may be due to the $\mathrm{Fe}$ and $\mathrm{Cu}$ diffusion from Inox316 to $\mathrm{CuInSe} \mathrm{S}_{2}$ film, this is why the presence of TiN/Ti bi-layer improves the surface condition of Inox 316 and reduces Iron presence from $9.7 \%$ to $1.9 \%$ and $\mathrm{Cr}$ from $3.8 \%$ to $0.5 \%$; this confirms its efficiency to improve the solar cell performance using Inox316 substrate.

\section{Keywords}

CuInSe 2 solar cells, Inox 316, TiN/Ti, diffusion barrier, roughness substrate.

\section{Introduction}

Chalcopyrite $\mathrm{CuInSe} 2$ based solar cells are now well established in the photovoltaic market due to their competitiveness to silicon $[1,2]$ and their lowest elaboration cost, especially by spray pyrolysis $[3,4]$. Soda-Calcic glasses are widely used as substrate support for thin films solar cells [5]; however, many disadvantages appeared such as their fragility and their rigidity in addition to their thermal instability. This situation reduces considerably the possible configurations and shapes $[6,7,8]$. Indeed, flexible devices show high potential in the fabrication cost reduction. It is due to the possibility to perform the Roll-to-Roll process using a small thin film deposition machine with highest production rate [9]. 
The idea of the glass substrate replacement is currently the subject of many studies, especially by using non-oxydable steel, which, if used very thin can lead to flexible devices. The purpose of use of Inox 316 has two main reasons: Firstly, to elaborate flexible $\mathrm{CuInSe}_{2}$ solar cells to widen the range of their use [10]. Secondly to reduce the Molybdenum matter which very expensive by this way, we lower the global $\mathrm{CuInSe} 2$ solar cell cost and thus we can make it competitive. Technically, the steel thermal conductivity [4] can contribute to the $\mathrm{CuInSe} 2$ grains growth in addition to a high mechanical resistivity against external forces. However, the thermal diffusion of the metallic elements (Iron and Chromium) may be detrimental $[1,11,12]$, in addition to an important substrate roughness $[13,14]$. T. Eisenbarth et al have shown that the Fe diffusion may reduce the solar cell quantum efficiency [13]. Also, residual constraints between Mo and Inox may lead to a peeling off and defects formation because of the thermal incompatibility during $\mathrm{CuInSe}_{2}$ deposition $[15,16]$. For this purpose, many works focused on the diffusion barrier deposited onto the metallic substrate, such as $\mathrm{ZnO}$ [17], $\mathrm{Cr}_{2} \mathrm{O}_{3}$ [11], $\mathrm{Cr}[13], \mathrm{Mo}-\mathrm{N}$ [18], $\mathrm{Al}_{2} \mathrm{O}_{3}$ [19], Ti/SiOx [20].

The present paper concerns the utilization of Titanium Nitride TiN on Inox 316 with molybdenum as rear contact [21]. However, in order to have high adhesion of TiN on Inox, we must pre-deposit a Titanium layer as sandwich between them. i-e, the diffusion barrier in the solar cells is the Bilayer TiN/Ti. Its role is the diffusion reduction, also by the reduction of the roughness. In another side, the thermal coefficient mean value for TiN is $9.10^{6} \mathrm{~K}^{-1}$ which may reduce considerably the constraints during $\mathrm{CuInSe}_{2}$ deposition (Inox thermal coefficient $=11 \times 10^{6} \mathrm{~K}^{-1}$, Mo thermal coefficient $\left.=5.9 \times 10^{6} \mathrm{~K}^{-1}\right)$ [16]. One can also notice from the electrochemical results done by H.Omrani et al. that the resistance to corrosion is significantly improved when TiN films are deposited onto Inox 316 substrate [22]. 
On the other hand, for chalcopyrite based solar cells, molybdenum exhibits the ideal choice as rear contact $[23,24]$, it occurs on the creation of an additional $\mathrm{MoSe} 2 / \mathrm{CuInSe} 2$ ohmic contact [25] which increases the free carriers'mobility and consequently the electrical conductivity [26]. However, titanium nitride has a considerable electrical conductivity [27,28], hence more, it can be used in the same position than Mo as a back contact. This proposal allows to reduce the thickness of Mo and giving a real economical challenge since titanium is less expensive than molybdenum [29], and yielded to cheaper solar cells.

\section{Experimental par}

$\mathrm{CuInSe}_{2}$ thin films were deposited by spray pyrolysis method using $20 \%$ vol. ethanol based solution. This one was prepared from copper dichloride $\left(\mathrm{CuCl}_{2} \cdot 2 \mathrm{H}_{2} \mathrm{O}\right)$ as copper source, Indium Trichloride $\left(\mathrm{InCl}_{3}\right)$ as Indium source and N,N,Diméthyl Sélén-urée $\left(\mathrm{C}_{3} \mathrm{H}_{8} \mathrm{~N}_{2} \mathrm{Se}\right)$ as

Selenium source $[3,30]$ (all chemical compounds were provided by Sigma Aldrich). The mixture concentration is $0.00795 \mathrm{M}$, the ratio $\mathrm{Cu}: \mathrm{In}$ :Se is fixed to $1: 1: 3,3$ and the excess in $\mathrm{C}_{3} \mathrm{H}_{8} \mathrm{~N}_{2} \mathrm{Se}$ is used to compensate the Selenium loss during deposition due its low evaporation energy with annealing [31]. $\mathrm{CuInSe}_{2}$ is formed according to the chemical reactions below [32]:

$$
\begin{array}{cl}
\mathrm{CuCl}_{2(\mathrm{aq})}+\mathrm{InCl}_{3(\mathrm{aq})}+ \\
3 \mathrm{NH}_{2}\left(\mathrm{CH}_{3}\right)_{2} \mathrm{NCSe}_{(\mathrm{aq})}+6 \mathrm{H}_{2} \mathrm{O}_{(\mathrm{l})}
\end{array} \longrightarrow \quad \begin{aligned}
& \mathrm{CuInSe}_{2}(\mathrm{~s})+3\left(\mathrm{CH}_{3}\right)_{2} \mathrm{NH}_{(\mathrm{g})}+3 \mathrm{NH}_{3(\mathrm{~g})}+ \\
& 3 \mathrm{CO}_{2(\mathrm{~g})}+\mathrm{H}_{2} \mathrm{Se}_{(\mathrm{g})}+4 \mathrm{HCl}_{(\mathrm{g})}+1 / 2 \mathrm{Cl}_{2(\mathrm{~g})}
\end{aligned}
$$

The solution was sprayed with an Argon flow rate of $12 \mathrm{ml} / \mathrm{mn}$ and a pressure of 2 Bar; the distance nozzle-substrate was fixed at $30 \mathrm{~cm}$. Deposition was made onto two substrate's type: glass and Inox 316 for a duration of $10 \mathrm{~min}$. Three substrate's temperatures were used: $\mathrm{T}_{\mathrm{S}}=$ $450^{\circ} \mathrm{C}, 500^{\circ} \mathrm{C}$ and $550^{\circ} \mathrm{C}$. 
The bilayer TiN/Ti diffusion barrier deposition was done using reactive Radio-Frequency (RF) magnetron sputtering technique in a Nitrogen-Argon gas atmosphere [33] onto metallic substrate Inox 316. For the sputtering deposition, a commercial Titanium target has been used with purity $99.95 \%$. A secondary pump connected to a primary pump ensures a based pressure of $4.10^{-7}$ mbar in the deposition chamber. Nitrogen injection was measured with a flow meter to access a total pressure $\mathrm{P}_{\mathrm{T}}=23$ mTorr. In order to avoid a films' contamination, the target undergoes a pre-sputtering for $90 \mathrm{mn}$ between each sample to make it cleaner.

Molybdenum films (rear contact for $\mathrm{CuInSe}$ ) were deposited by using cathodic DC sputtering with a Molybdenum target with 99.95\% purity, on two types of substrates: TiN/Ti/Inox 316 and Inox 316. After deposition, Mo films were annealed in Argon atmosphere at $550^{\circ} \mathrm{C}$ to have the same elaboration conditions for $\mathrm{CuInSe}_{2}$ by Spray Pyrolysis.

Structural properties were obtained using a X-ray diffractometer SEIFERT 3003 PTS $\left(\mathrm{K}_{\alpha 1}(\lambda=1.54050 \AA)\right)$, while the morphology of the surface was determined by Scanning Electron Microscopy (SEM) using a JEOL JSM-IT100 equipment; thicknesses were measured directly from the sample's lateral view. Chemical composition was analyzed by Energy Dispersive Spectroscopy (EDS) (Oxford Aztek). Optical properties were deduced from UVVisible spectroscopy with a Perkin Elmer Lambda 365 apparatus.

Figure1 illustrates the CuInSe 2 based solar cell structure with Inox 316 as flexible substrate and TiN/Ti diffusion barrier.

Table 1 summarized all the samples elaborated during this work with the corresponding experimental conditions.

\section{Results and Discussion}

\subsection{Optimization of the CuInSe 2 absorbing layer}


Figure 2a presents the XRD spectra for the $\mathrm{CuInSe}_{2}$ layers deposited onto glass substrates at different temperatures. One can remark the presence of four peaks in all diffractograms, indexed as (112), (220), (400), and (424) according to the JCPDS 23-0209 file of CuInSe 2 chalcopyrite [34-35]. This confirms that films are polycrystalline.

However, the diffraction of the $\mathrm{CuInSe}_{2}$ layer deposited at temperature of $550{ }^{\circ} \mathrm{C}$ shows four other peaks indexed as (301), (312), (323), (415) plans, according to the same JCPDS file 23 0209. Technically, the appearance of these peaks in this layer reveals to the superlattice reflections of the ordered chalcopyrite structure [36]. However, the peak (220) has a high and nearly constant intensity with all substrate temperatures with almost similar FWHMs (Figure 2b)

Figure 2c shows that the peak intensity (112) get improved and its diffraction angle $2 \theta$ changed towards the preferential position (JCPDS 23-0209) with an increases of the substrate temperature, this observed peak could be related to a shift in lattice parameters to make it larger, probably due to a slight variations in $\mathrm{Cu}$ content in the system [30]. An interesting decrease of the ratio $\mathrm{I}_{(220)} / \mathrm{I}_{(112)}$ (Figure $2 \mathrm{~d}$ ) confirms a good orientation for CISe-3 at $550^{\circ} \mathrm{C}$ [37].

Figure 3 presents the evolution as a function of the deposition temperature of the atomic ratios $(\mathrm{Cu} / \mathrm{In})$ and $(\mathrm{Se} / \mathrm{Cu})$ determined by EDS. Results show that the $(\mathrm{Cu} / \mathrm{In})$ ratios of the films vary from 1.0 to 1.1 and are similar to those of precursors. A loss in Selenium is observed when passing from the solution to the films [32], the solution presents a $(\mathrm{Se} / \mathrm{Cu})$ ratio comprised between 3.0 and 3.5 (to have an excess of Selenium) while the films present values of 1.8 and 1.9, close to 2.0. The excess of Selenium in the precursor solution has permitted the deposition of merely stoichiometric $\mathrm{CuInSe}_{2}$ layers. We notice also, a $\mathrm{Na}$ signal in the 
$\mathrm{CuInSe}_{2}$ layer (Figure 3b). Several researchers have shown this diffusion and also its critical role in the $\mathrm{CuInSe} 2$ absorbent layer to improve its performances [38,39].

SEM images in Figure 4 illustrate the $\mathrm{CuInSe}_{2}$ films morphology at different substrate temperature. Two kinds of grains were observed: big spherical grains (230 nm to $280 \mathrm{~nm}$ ) [31] for layers CISe-1 and CISe-2 deposited at $450^{\circ} \mathrm{C}$ and $500^{\circ} \mathrm{C}$ and small light grains shaped like eagles (200 $\mathrm{nm}$ to $400 \mathrm{~nm}$ ) for CISe-3 layer deposited at $550^{\circ} \mathrm{C}$, this can be explained by the effect of the supplied energy with the heating on atomized atoms [40].

Figure 5 shows the absorbance curves of $\mathrm{CuInSe}_{2}$ layers deposited at different substrate temperatures. Films have good optical absorption, especially in the visible range. Remarkably, A better absorption with the coefficient value of $9.16 .10^{4} \mathrm{~cm}-1$ at $\mathrm{T}_{\mathrm{S}}=550{ }^{\circ} \mathrm{C}$ has been obtained.

From the figure $5 \mathrm{~b}$, the energy gap decrease from $1.32 \mathrm{eV}$ to $1.07 \mathrm{eV}$ for $\mathrm{CuInSe} \mathrm{I}_{2}$ film deposited at $550^{\circ} \mathrm{C}$. According to Weidong Wang et al, this is due to the density of states at the interfaces and the defects energy level on the surface [41], however, S. Agilan et al, found an enhancement in the grain size [42], also, B.J. Babu et al, attributed the energy gap variation for layers deposited by techniques non using vacuum to the defects structure and grain boundaries [6].

\subsection{CuInSe 2 deposited onto Inox 316 substrate}

Figure 6a presents the XRD spectra for $\mathrm{CuInSe}_{2}$ layers deposited on glass and Inox 316 substrates and the Inox substrate alone. A polycrystalline structure of the Inox substrate is observed with peaks indexed as (111), (220) for $\mathrm{Cr}_{0.19} \mathrm{Fe}_{0.7} \mathrm{Ni}_{0.11}$ (JCPDS 33-0397), three peaks (110), (200) and (211) for Ni-Cr-Fe (JCPDS 85-1410) [43]. However, the film CISe-3 deposited onto glass depicts four peaks indexed as (112), (220), (400) and (424) of CuInSe, 
in addition, the film CISe-3 on Inox 316 exhibits two points: a total absence of peak (112), secondly, the detail displayed on the zoom (Figure 6c) notes that the CISe-5I peak is diffracted towards the same diffraction position of the peak (110) of Ni-Cr-Fe as mentioned on JCPDS 85-1410, we can also compare the obtained FWHMs to maintain the absence of the CuInSe 2 peaks on diffractogram of $\mathrm{CuInSe}_{2}$ deposited on Inox, the peak appeared toward $44.5^{\circ}$ resembles that of the Inox substrate (figure 6c). This good crystallinity of $\mathrm{CuInSe}_{2}$ on glass substrate (figure 6b) was somehow lost when deposition is performed on Inox 316; it is probably related to structural defects that appeared in parallel with the diffusion of metallic impurities [20].

Figure 7 shows the chemical ratios $(\mathrm{Cu} / \mathrm{In})$ and $(\mathrm{Se} / \mathrm{Cu})$ for $\mathrm{CuInSe}_{2}$ films deposited at $550^{\circ} \mathrm{C}$ on glass and Inox 316 substrates. One can remark that the $(\mathrm{Cu} / \mathrm{In})$ ratios are identical, while the $(\mathrm{Se} / \mathrm{Cu})$ ratio of the film on Inox 316 drops compared to the one on glass. This decrease is essentially due to the Selenium loss during deposition onto Inox; the CISe-3 layer deposited onto Inox is not stoichiometric, confirming its crystallographical results.

SEM images for CISe-3 on glass and Inox 316 are shown in Figure 8. One can notice that the morphology of the film deposited on glass is more homogeneous, the grains shaped like eagles in both cases, Grains are bigger on Inox $316(900 \mathrm{~nm}$ to $1200 \mathrm{~nm})$ than those observed on glass (200 nm to $400 \mathrm{~nm}$ ). The films surface looks like a spider canvas [44]. It should be noted that the state of morphology of $\mathrm{CuInSe}_{2}$ on Inox is not desirable; it also reflects degradation of $\mathrm{CuInSe}_{2}$ properties. The solution is the introduction of the TiN/Ti barrier layer to avoid the metallic elements diffusion and by mean of consequence to main the good $\mathrm{CuInSe} \mathrm{S}_{2}$ properties.

Figure 9 illustrates the EDS data of the CISe-3 layer deposited at $550^{\circ} \mathrm{C}$ on Inox substrate. Figure 9a shows that Inox is composed of three main elements: Iron, Chromium and Nickel. 
The EDS analysis of the film (Figure 9b) was made by decreasing the beam energy from 20 $\mathrm{KeV}$ to $8 \mathrm{KeV}$. This decrease permits to reduce the analyzed depth in sample in order to consider only the layer not the layer plus the substrate. We see that the substrate's elements $(\mathrm{Fe}, \mathrm{Cr}, \mathrm{Ni})$ reduce as beam energy decreases, in correlation to an increase of $\mathrm{Se}$ in the $\mathrm{CuInSe}_{2}$ layer. Nickel signal disappears at $8 \mathrm{KeV}, \mathrm{Fe}$ and $\mathrm{Cr}$ signals are still observed. One can conclude that at the tension of $8 \mathrm{KeV}$ allows to analyze only the (top) $\mathrm{CuInSe}_{2}$ layer and so, that observed $\mathrm{Fe}$ and $\mathrm{Cr}$ are diffused elements from the substrate in the $\mathrm{CuInSe}_{2}$ film $[35,45]$. This may be responsible for the crystallization loss of the CISe-3 layer deposited on Inox at $550^{\circ} \mathrm{C}$, as seen in Figure 6.

\subsection{TiN/Ti diffusion barrier:}

In order to avoid the diffusion of the substrate's elements to the CuInSe 2 films, diffusion barrier based on Titanium Nitride TiN has been used. Implantation of TiN on Inox substrate requires an intermediate layer of Titanium in order to ensure good adherence. The deposition conditions used are optimized: $\mathrm{P}_{\mathrm{RF}}=200 \mathrm{~W}, \%$ vol. $\mathrm{N}_{2}=50, \mathrm{p}_{\mathrm{T}}=20$ mTorr [46], thermally, the unstable behavior of Inox required a using of different deposition temperatures $T_{\mathrm{S}}=25^{\circ} \mathrm{C}$, $500^{\circ} \mathrm{C}$ or $700^{\circ} \mathrm{C}$.

XRD spectra in Figure 10 show scattered peaks along the diffraction domain. These are indexed (110), (200), (211), (330) and (220) according to our Inox substrate. However, it should be noted that for all the bilayers TiN/Ti, two TiN peaks (111) and (200) according to Titaium Nitride JCPDS 06-0642 are presented. These peaks confirm a polycrystalline structure of TiN. Nevertheless, relatively better intensities were observed for the film deposited at $25^{\circ} \mathrm{C}$ [47]. This temperature shows a small peak around $2 \theta=38^{\circ}$ correspond to the tie layer of Ti (111) according to JCPDS file 44-1294 [29]. 
SEM images in Figure 11 illustrate a high surface density with similar morphologies. One can distinguish circular grains filling the surface [48]. The curly condition of the substrate has also affected and shown on the deposited film.

EDS results in Figure 12 show that the (N/Ti) ratio in TiN/Ti bilayers decreases as the deposition temperature increases. The N/Ti ratio is close to stoichiometry for $\mathrm{T}_{\mathrm{S}}=25^{\circ} \mathrm{C}$, suggesting that the annealing of the Inox 316 substrate (deposition at high temperature) is prejudiciable to the deposition of stoichiometric TiN.

\subsection{Mo rear contact}

Mo films were deposited at $\mathrm{T}_{\mathrm{S}}=25^{\circ} \mathrm{C}$ by DC sputtering on Inox 316 and TiN/Ti/Inox 316 substrates. The samples underwent a heat treatment under $\mathrm{Ar}$ at a temperature of $550{ }^{\circ} \mathrm{C}$., in order to put this system in the same atmosphere as that of the $\mathrm{CuInSe}_{2}$ absorber and also to promote the impurities diffusion.

From SEM image in Figure 13, one can remark strong polishing streaks of the bare Inox substrate, reflecting its high roughness. The Mo layer above also shows a high roughness, however, it is reduced compared to the bare substrate and to the layer deposited on Inox alone when deposited on the TiN/Ti/Inox substrate. This will certainly reduce the electric leakage in the $\mathrm{CuInSe} 2$ solar cell [49].

M.Yazıc1 et al showed that the layer of TiN deposited on the Inox 316 makes it possible to enhance its hardness and its mechanical strength, particularly against wear [50]. Thus, it represents a better material catcher of this roughness compared to Mo.

The two deposited Mo layers have undergone annealing under Argon gas to quantify a possible Inox substrate's diffusion while annealing at the $\mathrm{CuInSe} \mathrm{Ie}_{2}$ deposition temperature. We have chosen $\mathrm{TS}=550^{\circ} \mathrm{C}$ which is the optimized value for obtaining stoichiometric crystalline 
$\mathrm{CuInSe}_{2}$ (see paragraph 3.1). Figure 14a shows the EDS contents of $\mathrm{Fe}$ and $\mathrm{Cr}$ for Mo layers deposited on Inox 316 and TiN/Ti/Inox 316 and annealed. There is a strong presence of Fe and $\mathrm{Cr}$ when the deposition was performed on Inox alone. it has clearly appeared in the EDS spectrum of Mo (Figure 14b) with the presence of low intensity of Fe and Cr lines. Unlike, the use of a TiN/Ti diffusion barrier obviously reduces the Fe rate (from $9.70 \%$ at. to 1.8 \%at.) and $\mathrm{Cr}(3.8 \%$ at. to $0.5 \%$ at. $)$ for the samples.

From these results, the bilayer TiN/Ti barrier diffusion efficiency is confirmed to avoid the migration of the substrate metallic elements in the rear contact Mo layer. The TiN/Ti/Inox 316 substrate will be soon used as a support for $\mathrm{CuInSe}_{2}$ solar cells.

\section{Conclusion}

The present study is dedicated to the use of a metallic Inox 316 substrate instead of glass for $\mathrm{CuInSe} \mathrm{I}_{2}$ based solar cells. This will help to improve properties such as flexibility and mechanical resistance. CuInSe 2 absorbing layers were deposited by spray pyrolysis onto glass and Inox 316 substrates. A comparative study has been performed showing a high crystallinity of $\mathrm{CuInSe}_{2}$ on glass at deposition temperature of $550^{\circ} \mathrm{C}$. No crystallinity was observed for $\mathrm{CuInSe}_{2}$ on Inox 316 substrate. EDS analysis for CuInSe $\mathrm{Ce}_{2}$ layers deposited on Inox 316 show that the ratio $(\mathrm{Cu} / \mathrm{In})$ is almost kept constant compared to the precursors solution, while the $(\mathrm{Se} / \mathrm{Cu})$ ratio is close to 2 confirming the stoichiometry of $\mathrm{CuInSe}_{2}$ on Inox 316. SEM images reveal that $\mathrm{CuInSe}_{2}$ grains are shaped like eagles on glass and Inox but they are bigger (900 $\mathrm{nm}$ to $1200 \mathrm{~nm}$ ) for $\mathrm{CuInSe}_{2} / \mathrm{Inox} 316$ than for $\mathrm{CuInSe}_{2} /$ glass; layers 'surface appear like a spider canvas. Different beam energies ( $8 \mathrm{kV}$ to $20 \mathrm{kV}$ ) have been used in EDS analysis to study the presence of metallic elements $(\mathrm{Fe}, \mathrm{Cr})$ in $\mathrm{CuInSe} 2$ layers, due to diffusion at high deposition temperature. When energy beam is low $(8 \mathrm{kV})$, only the $\mathrm{CuInSe} \mathrm{I}_{2}$ layer is analyzed, but $\mathrm{Fe}$ and $\mathrm{Cr}$ are still observed, demonstrating their diffusion from the Inox substrate. To 
avoid such diffusion, TiN/Ti bilayer was deposited on Inox 316 at $25^{\circ} \mathrm{C}, 500^{\circ} \mathrm{C}$ and $700^{\circ}$. $\mathrm{N} / \mathrm{Ti}$ ratio is close to stoichiometry for the $\mathrm{T}_{\mathrm{S}}=25^{\circ} \mathrm{C}$. By adding the rear Mo contact to the TiN/Ti barrier, it is found that the metallic $\mathrm{Fe}$ and $\mathrm{Cr}$ diffusion is drastically reduced: $\mathrm{Fe}$ content falls from 9.7 to $1.8 \%$ at., while $\mathrm{Cr}$ falls from 3.8 to $0.5 \%$ at. We conclude that the Inox 316 substrate can be used in $\mathrm{CuInSe}_{2}$ based solar cells by introducing a TiN/Ti diffusion barrier.

\section{Declaration of interests}

The authors declare that they have no known competing financial interests or personal relationships that could have appeared to influence the work reported in this paper.

\section{Aknowledgements}

Authors acknowledge both the two research teams involved in this work: the advanced materials and nanomaterials by sol-gel method team from URMPE of University M'hamed Bougara of Boumerdes, Algeria, and IETR FunMAT team from University of Rennes, France. This work was performed with the followship PNE provided by the Higher ministry of Algeria. This work was supported by the European Union through the European Regional Development Fund (ERDF) and by the Ministry of Higher Education and Research of France, Brittany Région and Côtes d'Armor Département through the CPER Project MATECOM. This publication was also supported by Saint Brieuc Agglomération and the Syndicat de Gestion du Pole Universitaire de Saint Brieuc (France).

\section{References}

[1] S.-J. Lee, Y.-H. Chen, H. Sung-Cheng, Y.-C. Lin, J.-W. Chang, T.- L. Poona, W. Cheng $\mathrm{Ke}$, Improved performance of amorphous Si thin-film solar cells on 430 stainless steel 
substrate by an electrochemical mechanical polishing process, Journal of Alloys and Compounds 558 (2013) 95-98.

[2] Sascha Sadewasser, Pedro M.P. Salomé, Humberto Rodriguez-Alvarez, Materials efficient deposition and heat management of CuInSe2 microconcentrator, Solar Energy Materials \& Solar Cells 159 (2017) 496-502

[3] T. Terasako, Y. Uno, T. Kariya, S. Shirakata, Structural and optical properties of In-rich $\mathrm{Cu}-\mathrm{In}-\mathrm{Se}$ polycrystalline thin films prepared by chemical spray pyrolysis, Solar Energy materials and Solar Cells 90(2006) 262-275 .

[4] L.P. Deshmukh, R.V. Suryawanshi, E.U. Masumdar, M. Sharon, $\mathrm{Cu}_{1-\mathrm{x}} \mathrm{In}_{\mathrm{x}} \mathrm{Se}_{2}$ thin films:

Deposition by spray pyrolysis and characteristics, Solar Energy 86 (2012) 1910-1919.

[5] Shanza Rehan, Jihyun Moon, Tae Gun Kim, Jihye Gwak, Juran Kim, Jeong Won Kim , William Jo, Seung Kyu Ahn SeJin Ahn, Role of Na in solution-processed CuInSe2 (CISe) devices: A different story for improving efficiency, Nano Energy, Volume 48, June 2018, Pages 401-412

[6] B.J. Babu, S. Velumani, A. Kassiba , R. Asomoza , J.A. Chavez-Carvayar, Junsin Yi, Deposition and characterization of graded $\mathrm{Cu}\left(\operatorname{In}_{1-\mathrm{x}} \mathrm{Ga}_{\mathrm{x}}\right) \mathrm{Se}_{2}$ thin films by spray pyrolysis, Materials Chemistry and Physics 162 (2015) 59-68.

[7] H. Liu, Z. Jin, J. Wang, J. Ao, G. Li, Well-dispersed CuInSe 2 nanoplates and nanoplatesink-coated thin films for photovoltaic application by a triethylene glycol based solution process, Materials Letters 94 (2013) 1-4. 
[8] S. Hamrouni, M..S. AlKhalifah, M.F. Boujmil, K. Ben Saad, Preparation and characterization of CuInSe 2 electro deposited thin films annealed in vacuum Applied Surface Science 292 (2014) 231236.

[9] P. Reinhard, A. Chirila, P. Blosch, F. Pianezzi, S. Nishiwaki, S. Buecheler, A.N. Tiwari, Review of progress toward 20\% efficiency flexible CIGS solar cells and manufacturing issues of solar modules, IEEE J. Photovoltaics 3 (1) (2013) 572- 580.

[10] Karsten Otte, Liudmila Makhova, Alexander Braun, Igor Konovalov, Flexible $\mathrm{Cu}(\mathrm{In}, \mathrm{Ga}) \mathrm{Se} 2$ thin-film solar cells for space application, Thin Solid Films 511 - 512 (2006) $613-622$.

[11] J.-K. Sim, S.-K. Lee, J.-S. Kim, K.-U. Jeong, H.-K. Ahn,Cheul-Ro Lee, Efficiency enhancement of CIGS compound solar cell fabricated usinghomomorphic thin $\mathrm{Cr}_{2} \mathrm{O}_{3}$ diffusion barrier formed on stainless steelsubstrate, Applied Surface Science 389 (2016) 645650.

[12] S.D. Lu, Z.B. Wang, K.Lu Enhanced chromizing kinetics of tool steel by means of surface mechanical attrition treatment, Materials Science and Engineering A 527 (2010) 9951002.

[13] T. Eisenbarth, R. Caballero, C. A Kaufmann, A. Eicke, T. Unold, Influence of iron on defect concentrations and device performance for $\mathrm{Cu}(\mathrm{In}, \mathrm{Ga}) \mathrm{Se}_{2}$ solar cells on stainless steel substrates, Progress in Photovoltaics : Research and Applications 20 (2012) 568-574.

[14] F. Pianezzi, A. Chirilă, P. Blösch, S. Seyrling, S. Buecheler, L. Kranz, C. Fella and A. N. Tiwari, Electronic properties of $\mathrm{Cu}(\mathrm{In}, \mathrm{Ga}) \mathrm{Se}_{2}$ solar cells on stainless steel foils without diffusion barrier, Photovoltaics : Research and Applications 20 (2012) 253-259. 
[15] T. Hanabusa, K. Kusaka, O. Sakata, Residual stress and thermal stress observation in thin copper films, Thin Solid Films 459 (2004) 245-248B.

[16] F. Kessler, D. Rudmann, Technological aspects of flexible CIGS solar cells and modules, Solar Energy 77 (2004) 685-695.

[17] C.Y. Shi, Yun Sun, Qing He, F.Y. Li, J.C. Zhao, Cu(In,Ga)Se2 solar cells on stainlesssteel substrates covered with $\mathrm{ZnO}$ diffusion barriers, Solar Energy Materials Solar Cells 93 (2009) 654-656.

[18] B.J. Mueller, A. Fotler, V. Haug, F. Hergert, S. Zweigart, U.Herr, Influence of Mo-N as diffusion barrier in Mo back contacts for, $\mathrm{Cu}(\mathrm{In}, \mathrm{Ga}) \mathrm{Se}_{2}$ solar cells, Thin Solid Films 612 (2016) 186-193.

[19] K. Herz, A. Eicke, F. Kessler, R. Wachter, M. Powalla, Diffusion barriers for CIGS solar cells on metallic substrates, Thin Solid Films 431-432 (2003) 392-397.

[20] R. Wuerz, A. Eicke, M. Frankenfeld, F. Kessler, M. Powalla, P. Rogin, O. Yazdani-Ass1 CIGS thin-film solar cells on steel substrates, Thin Solid Films 517 (2009) 2415-2418.

[21] D. Zhou, H. Zhu, X. Liang, C. Zhang, Z. Li, Y. Xu, J. Chen, L. Zhang, Y. Mai, Sputtered molybdenum thin films and the application in CIGS solar cells, Applied Surface Science 362 (2016) 202-209.

[22] M. Omrani, M. Habibi, R. Amrollahi, A. Khosravi, Improvement of corrosion and electrical conductivity of $316 \mathrm{~L}$ stainless steel as bipolar plate by TiN nanoparticle implantation using plasma focus, International Journal of Hydrogen Energy 37 (2012) 1467614686. 
[23] S. Ashour and S. Alkuhaimi , H. Moutinho, R. Matson, F. A. Elfotouh, Junction formation and characteristics of CdS/CulnSe $/$ metal Interfaces, Thin Solid Films 226 (1993) $129-134$.

[24] Anjun Han, Xian Wang, Xiaohui Liu, Yongliang Huang, Fanying Meng, Zhengxin Liu, Improvement of $\mathrm{Ga}$ distribution in $\mathrm{Cu}(\mathrm{In}, \mathrm{Ga})(\mathrm{S}, \mathrm{Se}) 2$ film by pretreated Mo back contact, Solar Energy, 162 (2018) 109-116

[25] Y.-C. Lin, Y.-T. Hsieh, C.-M. Lai, H.-R. Hsu, Impact of Mo barrier layer on the formation of $\mathrm{MoSe} 2$ in $\mathrm{Cu}(\mathrm{In}, \mathrm{Ga}) \mathrm{Se}_{2}$ solar cells, Journal of Alloys and Compounds 661 (2016) 168-175.

[26] M. Theelen, S. Harel, M. Verschurena, M. Tomassini, A. Hovestad, N. Barreau, J. van Berkum, Z. Vroon, M. Zeman Influence of $\mathrm{Mo} / \mathrm{MoSe}_{2}$ microstructure on the damp heat stability of the $\mathrm{Cu}(\mathrm{In}, \mathrm{Ga}) \mathrm{Se}_{2}$ back contact molybdenum, Thin Solid Films 612 (2016) 381392.

[27] Jingguo Li, Lian Gao, Jingkun Guo, Mechanical properties and electrical conductivity of $\mathrm{TiN}-\mathrm{Al}_{2} \mathrm{O}_{3}$ nanocomposites, Journal of the European Ceramic Society 23.1 (2003) 69-74.

[28] M. Omrani, M. Habibi, M. Saeed. M. Birjandi, Enhanced electrical conductivity of two layers AlN-TiN coating on SS316L as bipolar plate using plasma focus device, International Journal of Hydrogen Energy 41 (2016) 5028-5036.

[29] Joyce A and OberUS 2017 Mineral commodity summaries U.S. Geological Survey 202 (Reston, Virginia: U.S. Geological Survey) pp 202 
[30] T. Terasako, S. Inoue, T. Kariya, S. Shirakata, Three-stage growth of $\mathrm{Cu}-\mathrm{In}-\mathrm{Se}$ polycrystalline thin films by chemical spray pyrolysis, Solar Energy Materials \& Solar Cells 91 (2007) 1152-1159.

[31] R. Yan, D. Gauthier, G. Flamant, Y. Wang, Behavior of selenium in the combustion of coal or coke spiked with Se, Combustion and Flame 138 (2004) 20-29.

[32] B.J. Brown, C.W. Bates Jr., Preparation and characterization similarities in the chemical mechanisms of $\mathrm{CuInSe}_{2}$ and $\mathrm{CdS}$ thin film formation by chemical spray pyrolysis, Thin Solid Films 188 (1990) 301-305.

[33] K. Vasua, M. Ghanashyam Krishna, K.A. Padmanabhan, Substrate-temperature dependent structure and composition variations in RF magnetron sputtered titanium nitride thin films, Applied Surface Science 257 (2011) 3069-3074.

[34] J.-S. Hahn, G. Park, J. Lee, J. Shim, Synthesis of CuInSe 2 nanoparticles in an oleic acid solution for application in thin film solar cells, Journal of Industrial and Engineering Chemistry 21 (2015) 754-759.

[35] M. Ghali, M. Elnimr, Gh.F. Ali, B. Yousif, Colloidal CuInSe 2 nanocrystals and thin films for low-cost photovoltaics, Optical Materials 55 (2016) 145-152.

[36] E.P.Zaretskaya, V.F.Gremenyuk, V.B.Zalesski, V.A.Ivanov, I.V.Viktorov, V.I.Kovalevski, O.VErmakov, T.P.Leonova, The properties of $\mathrm{CuInSe}_{2}$ films obtained by selenation of $\mathrm{Cu}-\mathrm{In}$ layers, Technical Physics 45 (2000) 1371-1373.

[37] Muhammad Saifullah, Jihye Gwak, Joo Hyung Park, Seungkyu Ahn, Kihwan Kim, Young Joo Eo, Jae Ho Yun, Effect of substrate temperature during the three-stage process on the CuInSe2 solar cell characteristics, Current Applied Physics 17 (2017) 1194-1201. 
[38] Lorelle Mansfield.M, Ingrid.L Repins, Joel.W Pankow, Matthew.R Young, Clay Dehart, Rajalakshmi Sundaramoorthy, Carolyn.L Beall, Bobby To, Michael D Carducci, and David M Honecker. Sodium-Doped Molybdenum Targets for Controllable Sodium Incorporation in CIGS Solar Cells. In Proceedings of the 37th IEEE Photovoltaic Specialists Conference (PVSC 37) Seattle, Washington, number July, 2011.

[39] Ju-heon Yoon, Won-mok Kim, Jong-keuk Park, Young-joon Baik, Tae-yeon Seong, and Jeung-hyun Jeong. Control of the preferred orientations of $\mathrm{Cu}(\mathrm{In}, \mathrm{Ga}) \mathrm{Se}_{2}$ films and the photovoltaic conversion efficiency using a surface-functionalized molybdenum back contact. Progress in Photovoltaics : Research and Applications, December 2012.

[40] G.Ojeda-Barrero , A.I.Oliva-Avilés, A.I.Oliva, R.D.Maldonado, M.Acosta, G.M.AlonzoMedina, Effect of the substrate temperature on the physical properties of sprayed-CdS films by using an automatized perfume atomizer, Materials Science in Semiconductor Processing 79 (2018) 7-13.

[41] Agilan, D. Mangalarajb, Sa.K. Narayandassb, G. Mohan Raomm Effect of thickness and substrate temperature on structure and optical band gap of hot wall-deposited CuInSe2 polycrystalline thin films, Physica B 365 (2005) 93-101.

[42] Weidong Wang, Zhengguo Jin, Hui Liu, Haiyan Du, Preparation and characteristics of CuInSe2 thin films by dip-coating method using its nanocrystal ink, Materials Letters 65 (2011) 2895-2898.

[43] F. C. Borges, W. R. de Oliveira, J. Kublitski, Mechanical, structural and tribological properties ef super-austenitic stainless steel submitted at solution heat treatement, ISNN 15177076 artigo 11584, pp.160-168, 2015. 
[44] Huanhuan Kou, Xin Zhang, Yimin Jiang, Jiajia Li, Shengjiao Yu, Zhixiang Zheng, Chunming Wang, Electrochemical atomic layer deposition of a $\mathrm{CuInSe}_{2}$ thin film on flexible multi-walled carbon nanotubes/polyimide nanocomposite membrane: Structural and photoelectrical characterizations, Electrochimica Acta 56 (2011) 5575-5581.

[45] X.Liang, H.Zhu, J.Chen, D.Zhou, C.Zhang, Y.Guo, X.Niu, Z.Li, Y.Mai, Substrate temperature optimization for $\mathrm{Cu}(\mathrm{In}, \mathrm{Ga}) \mathrm{Se}_{2}$ solar cells on flexible stainless steels, Applied Surface Science 368 (2016) 464-469.

[46] Bachir Eddine Messaid, Claire Le Paven, Razika Zair Talaighil, Florent Marlec, Ratiba Benzerga, Laurent Le Gendre and Fayçal Bensouici, Partial replacement in CISe solar cells of the molybdenum layer by an epitaxial Titanium Nitride thin film deposited onto $\mathrm{MgO}$ substrate, Mater. Res. Express 5 (2018) 106408

[47] Junwei Fu, Qiangqiang Nie, Wenxiu Qiu, Jiajun Sun, Feng Li, Yucheng Wu, Crystallography and growth mechanism of $\mathrm{TiN}$ in $\mathrm{Fe}-17 \mathrm{Cr}$ stainless steel during solidification, Journal of Materials Processing Technology, 253 (2018) 43-50

[48] Weiwei Xiao, Hua Deng Shuliang Zou, Yuhong Ren, Dewen Tang, Ming Lei, Changfei Xiao, Xi Zhou, Yao Chen, Effect of roughness of substrate and sputtering power on the properties of TiN coatings deposited by magnetron sputtering for ATF, Journal of Nuclear Materials 509 (2018) 542-549. 
[49] F.Z.Dahou, L.Cattin, J.Garnier, J.Ouerfelli, M.Morsli, G.Louarn, A.Bouteville, A.Khellil, J.C.Bernède, Influence of anode roughness and buffer layer nature on organic solar cells performance, Thin Solid Films, 518.21 (2010) 6117-6122.

[50] M.Yazıcı, H.Kovacı, A.F.Yetim, A.Çelik, Structural, mechanical and tribological properties of $\mathrm{Ti}$ and $\mathrm{TiN}$ coatings on 316L stainless steel, Ceramics International 44 (2018) 14195-14201.

\section{List of figures}

Figure 1: Structure of a CuInSe/2/Mo/TiN/Ti/Inox 316 solar cell.

Figure 2: (a) XRD of $\mathrm{CuInSe} 2$ layers deposited on glass at different substrate temperatures, (b) (220) peak detail and FWHM value, (c) (112) peak detail and (d) $I_{220} / I_{112}$ ratio according to Ts.

Figure 3: (a) chemical ratios $(\mathrm{Cu} / \mathrm{In})$ and $(\mathrm{Se} / \mathrm{Cu})$ for films and for precursors solution at deposited temperature from $400^{\circ} \mathrm{C}$ to $600^{\circ} \mathrm{C}$, (b) CuInSe 2 layer EDS spectrum.

Figure 4: SEM images for $\mathrm{CuInSe}_{2}$ films deposited onto glass substrates at different temperatures.

Figure 5: (a) Absorbance spectra and absorption coefficient for $\mathrm{CuInSe}_{2}$ layers deposited at different temperatures. (b) The variation of the gap band $\mathrm{Eg}$ for the three $\mathrm{CuInSe}_{2}$ films deposited at different temperatures

Figure 6: (a) XRD spectra for $\mathrm{CuInSe} 2$ deposited at $\mathrm{T}_{\mathrm{S}}=550^{\circ} \mathrm{C}$ on glass and Inox 316 and for the Inox 316 substrate,(b) Zoom on the peak (112) for the three samples (c) Zoom on the peak (220) for the three samples with different FWHM

Figure 7: $\mathrm{Cu} / \mathrm{In}$ and $\mathrm{Se} / \mathrm{Cu}$ ratios of the film CISe-3 deposited on glass and Inox at $550^{\circ} \mathrm{C}$.

Figure 8: SEM images of CISe-3 deposited at $\mathrm{T}_{\mathrm{S}}=550^{\circ} \mathrm{C}$ on glass and Inox 316.

Figure 9: atomic composition (a) in Inox 316, (b) CISe-3 layer on Inox 316 for different energy beams. 
Figure 10: XRD spectra of TiN/Ti layers deposited onto Inox 316 substrate at different substrate temperatures.

Figure 11: SEM images, for the bilayers 'surface TiN/Ti deposited at different substrate temperatures on Inox 316.

Figure 12: N/Ti ratio of TiN/Ti films deposited on Inox 316 at different temperatures.

Figure 13: SEM images of (a) substrate Inox 316, (b) Mo/Inox 316 layer, (c) Mo/TiN/Ti/Inox 316 layer.

Figure 14: (a) \% atomic contents of $\mathrm{Fe}$ and $\mathrm{Cr}$ in Mo films deposited on Inox316 and on TiN/Ti/Inox 316 after an annealing at $550^{\circ} \mathrm{C}$ under argon, (b) EDS spectrum of Mo deposited onto Inox 316.

\section{Figures:}

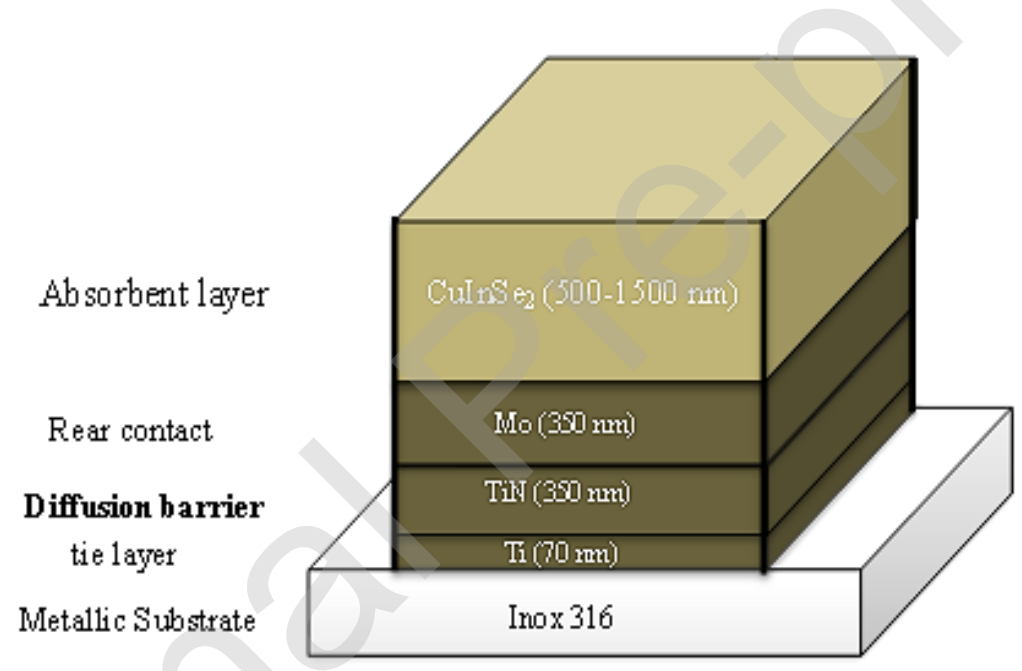

Figure 1. Structure of a CuInSe2/Mo/TiN/Ti/Inox 316 solar cell. 

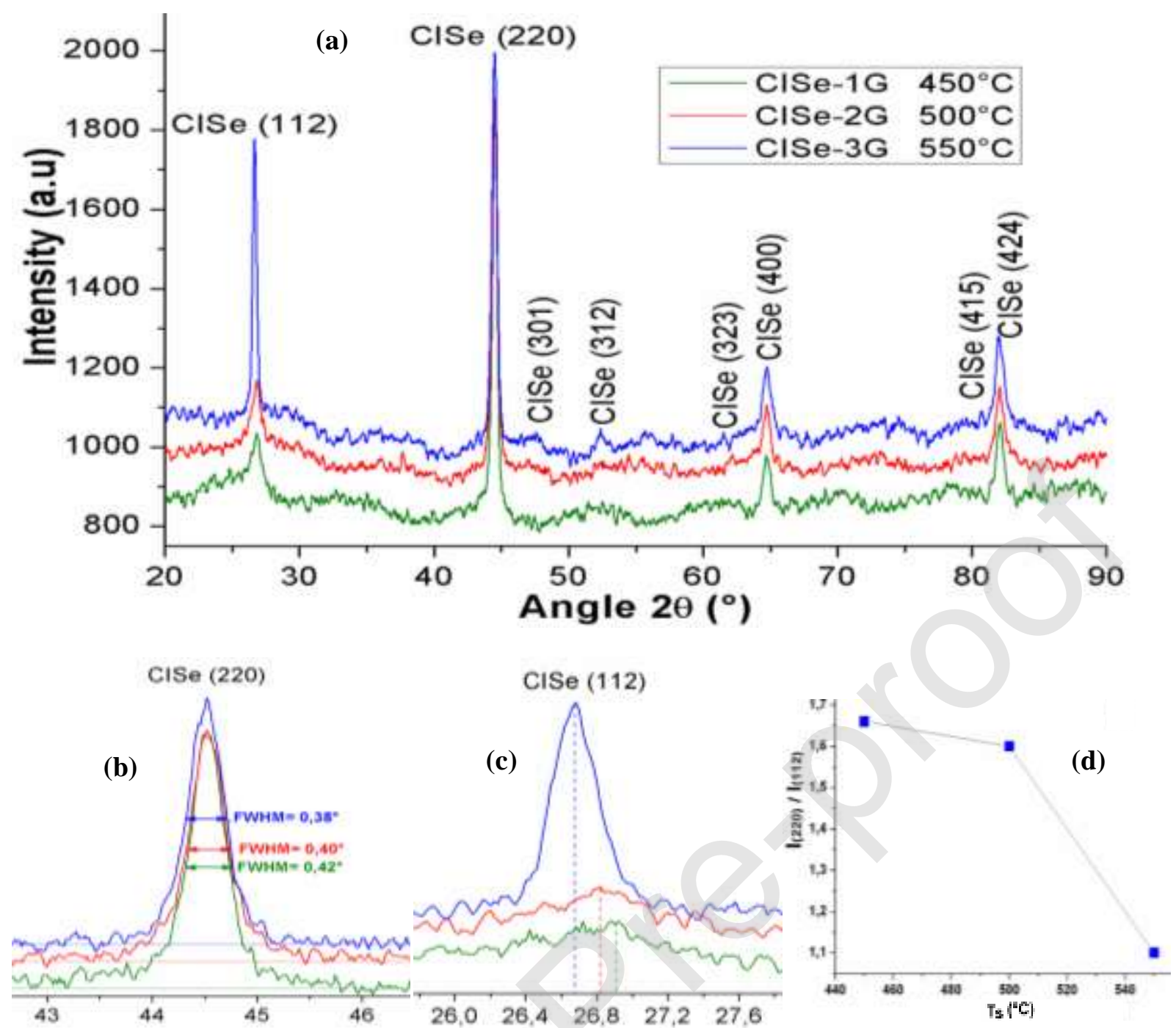

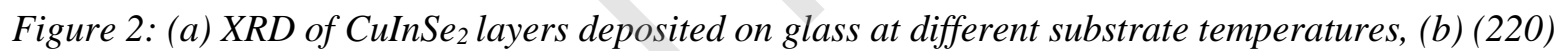
peak detail and FWHM value, (c) (112) peak detail and (d) $I_{220} / I_{112}$ ratio according to $T_{S}$.
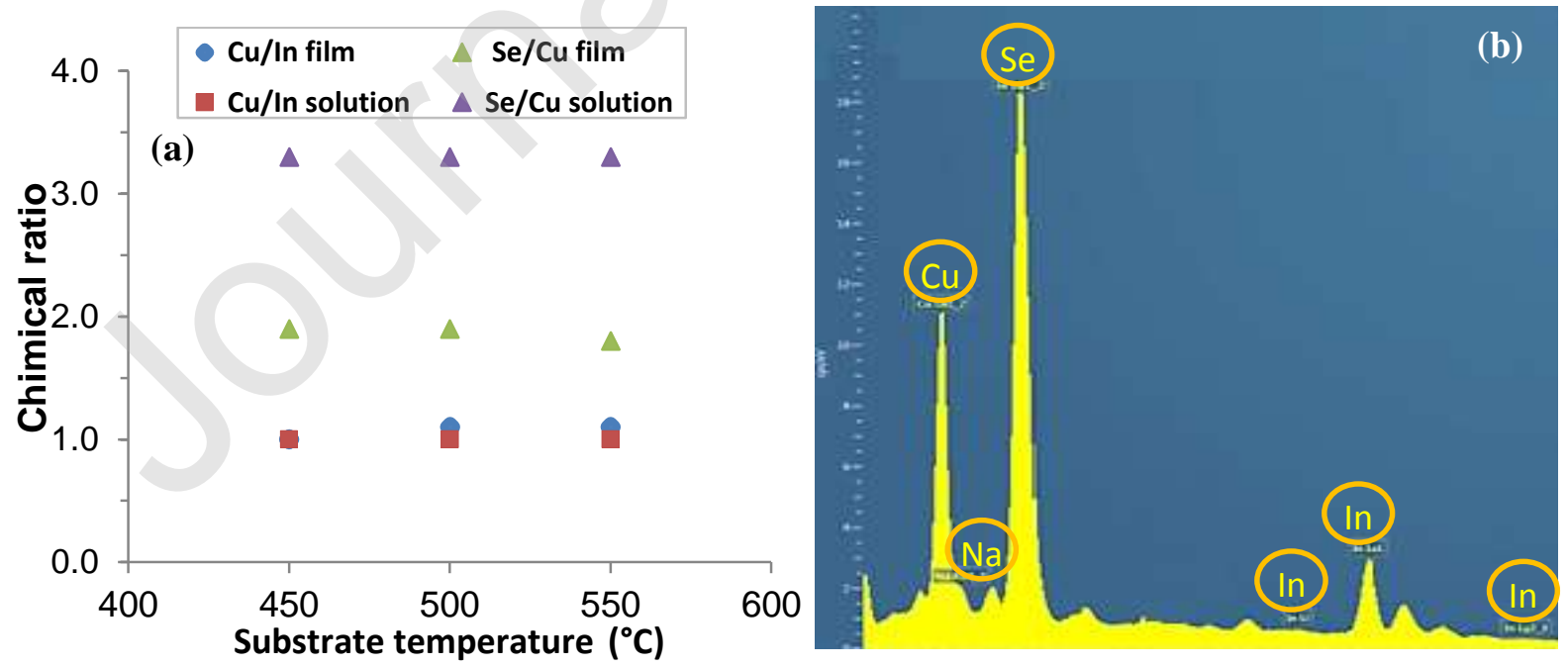

Figure 3. (a) chemical ratios $(\mathrm{Cu} / \mathrm{In})$ and $(\mathrm{Se} / \mathrm{Cu})$ for films and for precursors solution at deposited temperature from $400^{\circ} \mathrm{C}$ to $600^{\circ} \mathrm{C}$, (b) CuInSe $e_{2}$ layer EDS spectrum. 


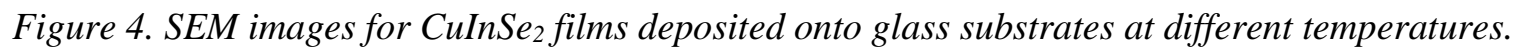
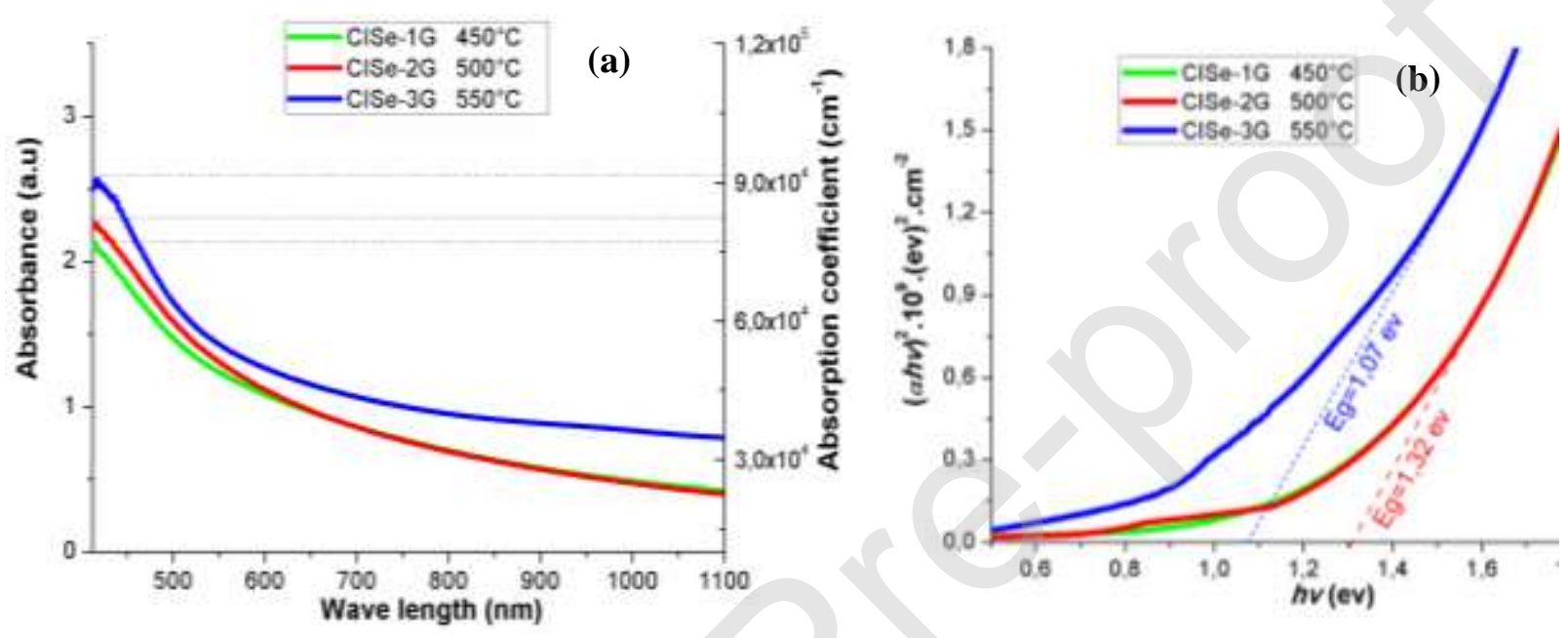

Figure 5: (a) Absorbance spectra and absorption coefficient for CuInSe 2 layers deposited at different

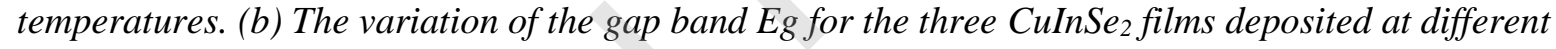
temperatures 


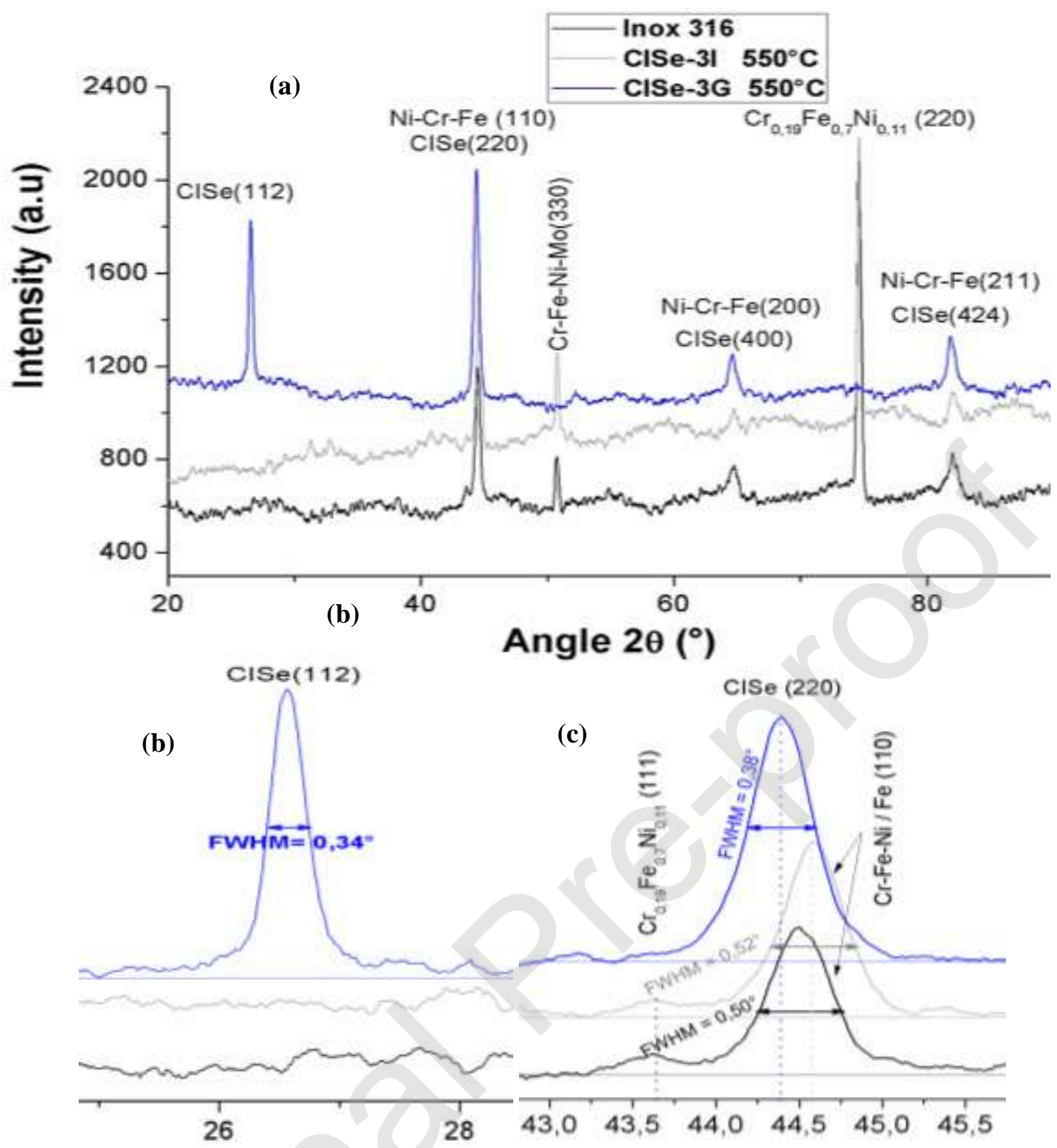

Figure 6: (a) XRD spectra for CuInSe2 deposited at $T_{S}=550^{\circ} \mathrm{C}$ on glass and Inox 316 and for the Inox 316 substrate,(b) Zoom on the peak (112) for the three samples (c) Zoom on the peak (220) for the three samples with different FWHM

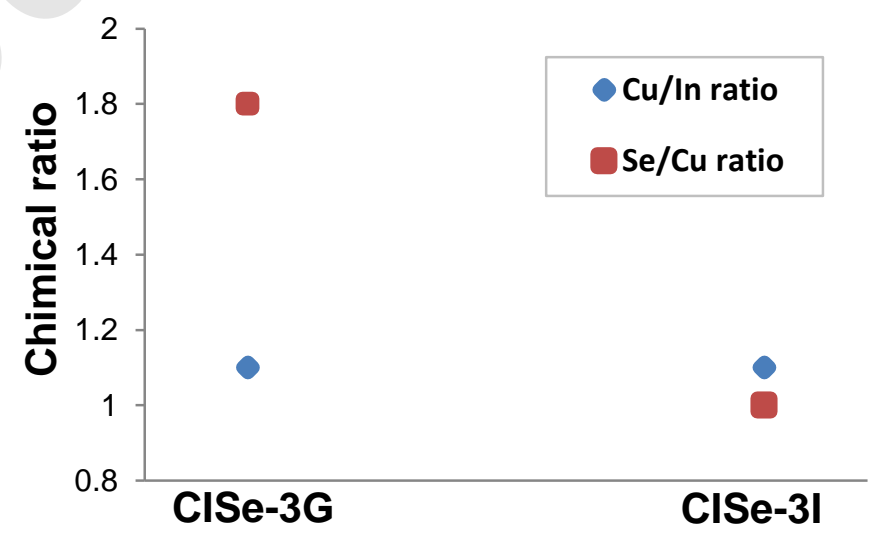


Figure 7. $\mathrm{Cu} / \mathrm{In}$ and $\mathrm{Se} / \mathrm{Cu}$ ratios of the film CISe-3 deposited on glass and Inox at $550^{\circ} \mathrm{C}$.
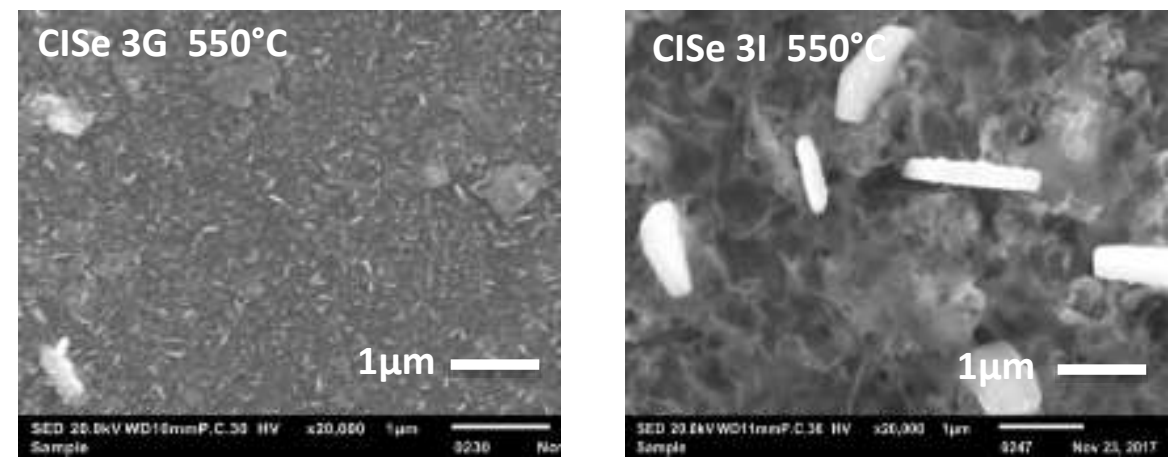

Figure 8. SEM images of CISe-3 deposited at $T_{S}=550^{\circ} \mathrm{C}$ on glass and Inox 316 .
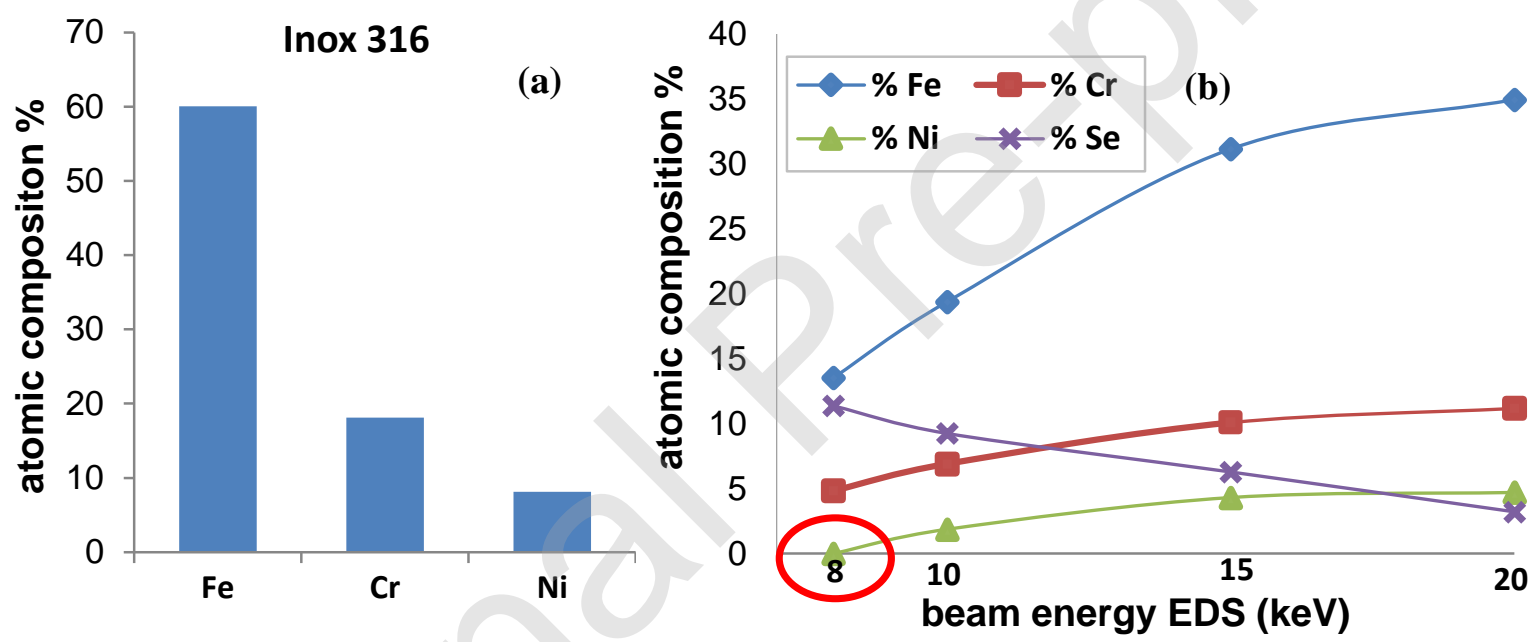

Figure 9. Atomic composition (a) in Inox 316, (b) CISe-3 layer on Inox 316 for different energy beams. 


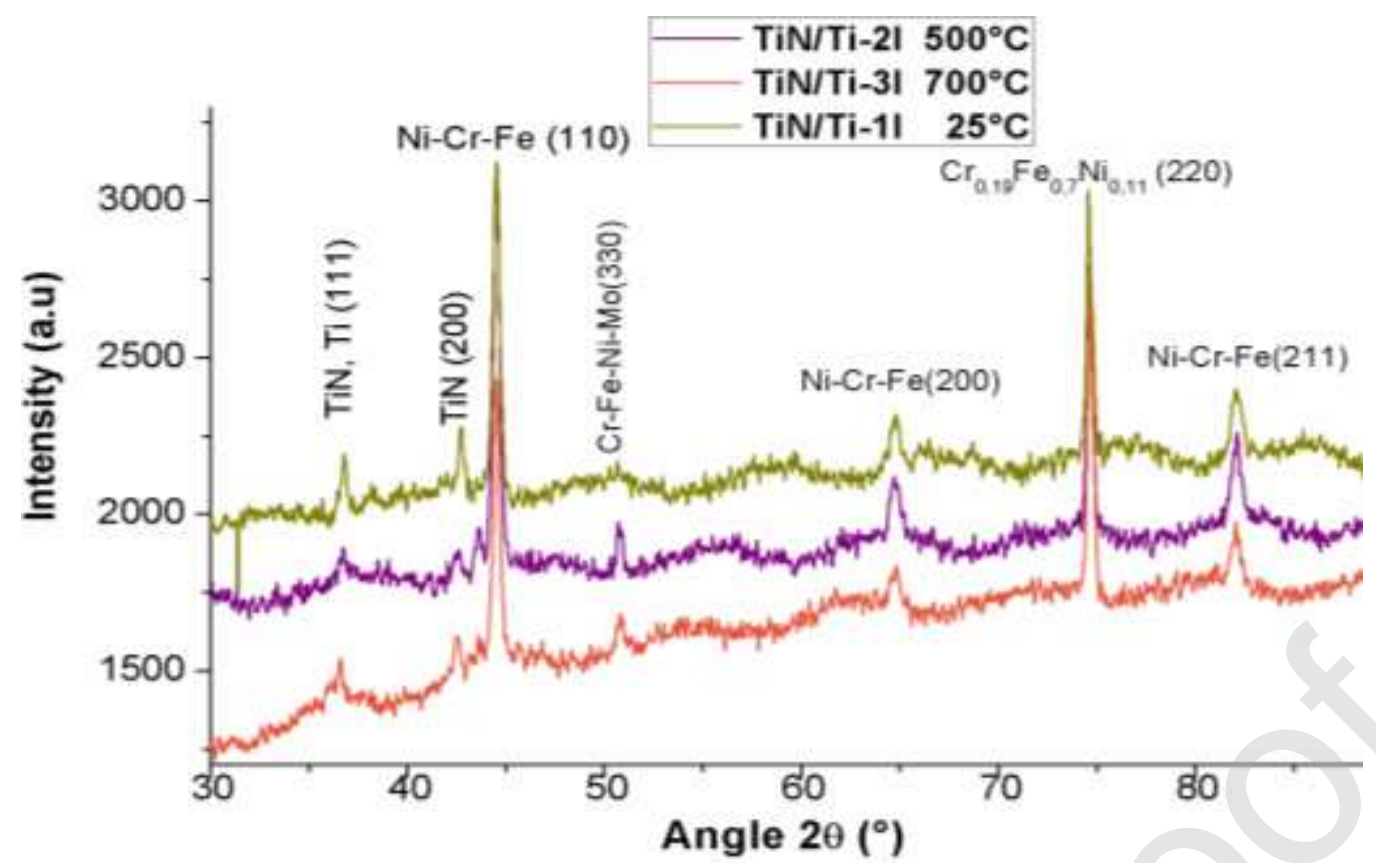

Figure 10. XRD spectra of TiN/Ti layers deposited onto Inox 316 substrate at different substrate temperatures.
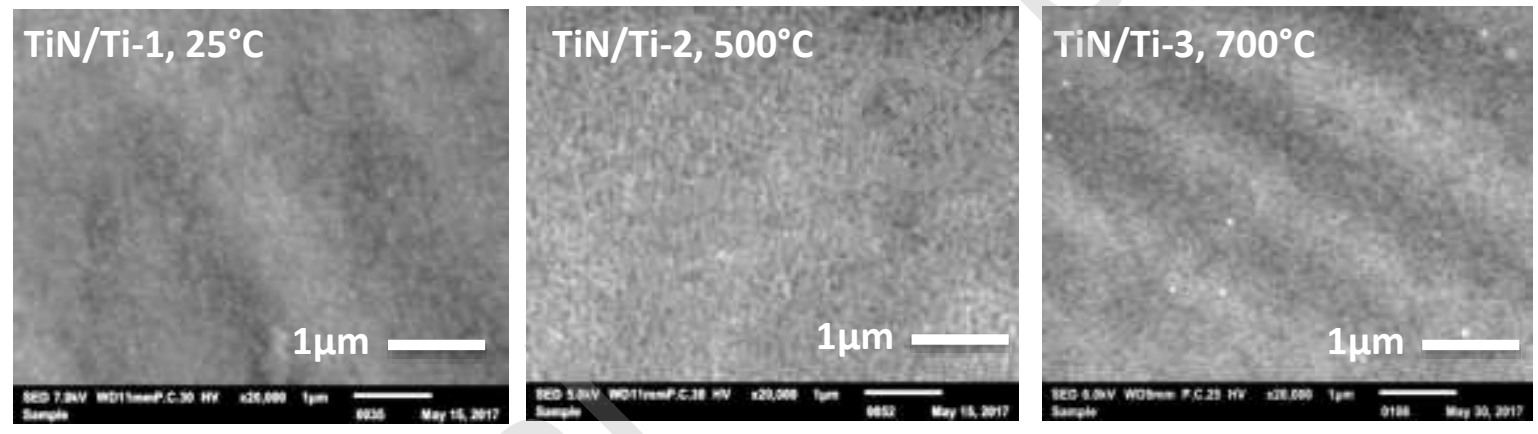

Figure 11. SEM images, for the bilayers 'surface TiN/Ti deposited at different substrate temperatures on Inox 316.

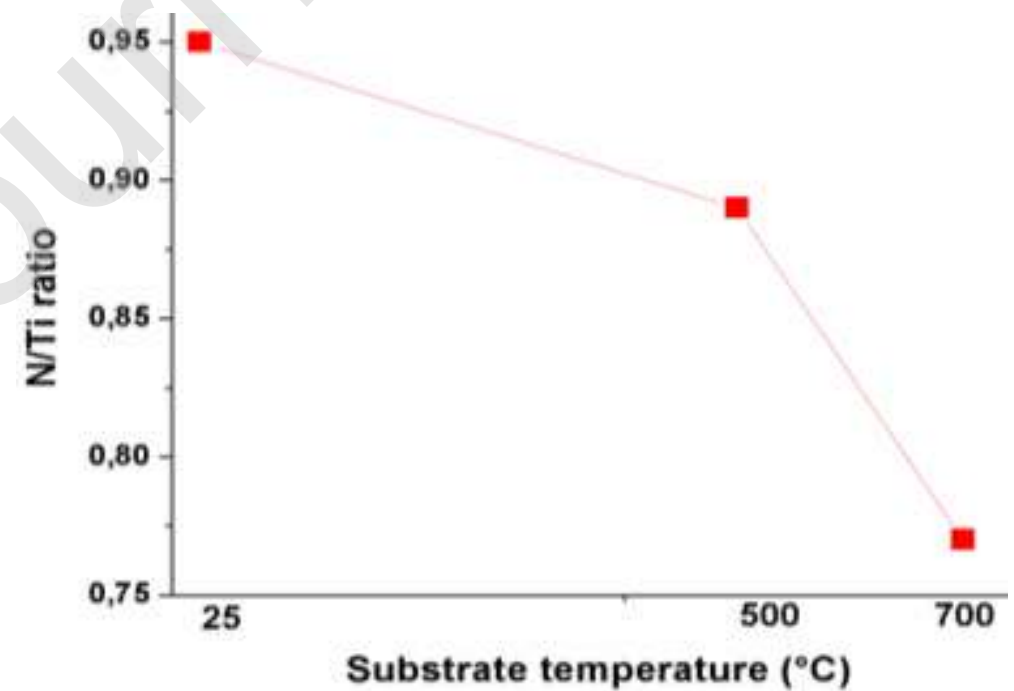

Figure 12. N/Ti ratio of TiN/Ti films deposited on Inox 316 at different temperatures. 

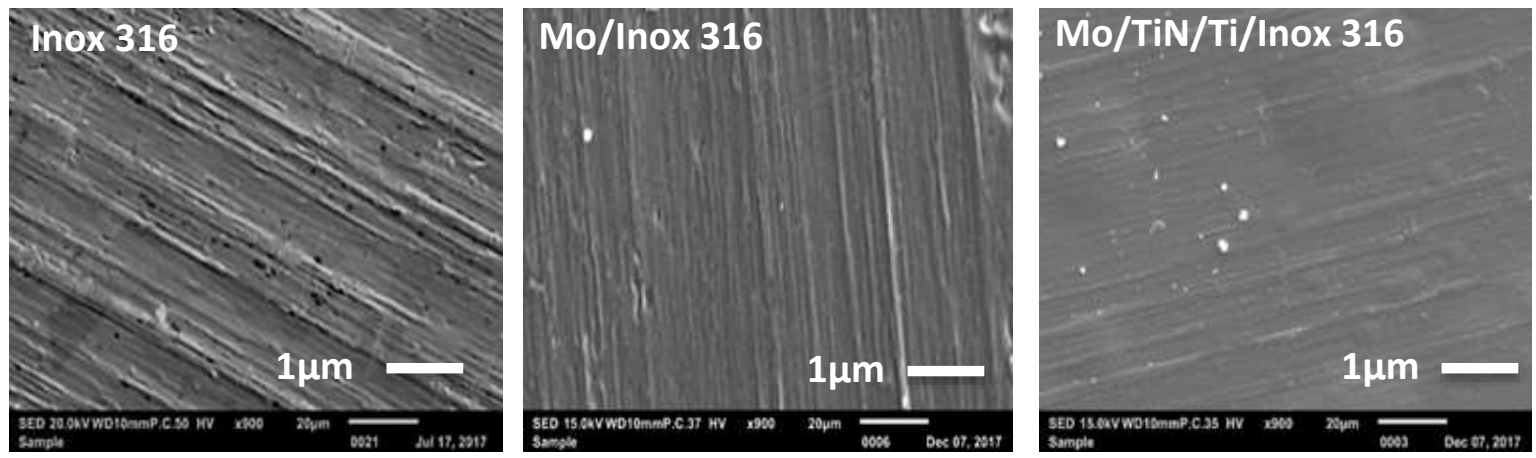

Figure 13. SEM images of substrate Inox 316, Mo layer onto Inox 316 and Mo layer onto TiN/Ti/Inox 316.
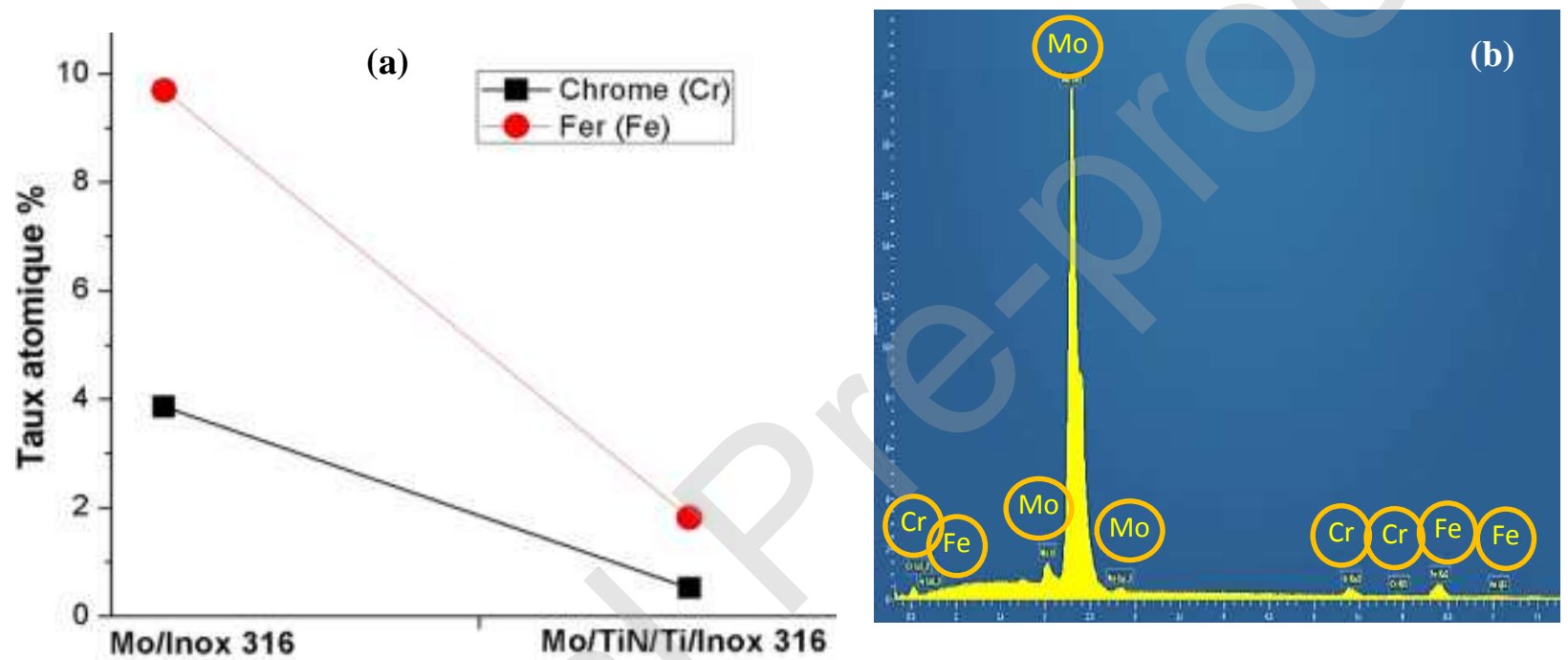

Figure 14. (a) \% atomic contents of $\mathrm{Fe}$ and $\mathrm{Cr}$ in Mo films deposited on Inox316 and on TiN/Ti/Inox 316 after an annealing at $550^{\circ} \mathrm{C}$ under argon, (b) EDS spectrum of Mo deposited onto Inox 316.

\section{List of tables}

Table1: Prepared CuInSe, TiN/Ti and Mo films along with their deposition conditions. 


\section{Tables}

Table1: Prepared CuInSe, , TiN/Ti and Mo films along with their deposition conditions.

\begin{tabular}{|c|c|c|c|c|}
\hline Films & Substrate & $\begin{array}{c}\text { Deposition } \\
\text { technique }\end{array}$ & Fixed parameters & Substrate Temperature \\
\hline CISe-1G & \multirow{3}{*}{ Glass } & \multirow{4}{*}{$\begin{array}{c}\text { Spray } \\
\text { Pyrolysis }\end{array}$} & \multirow{4}{*}{$\begin{array}{c}\text { Argon pressure } \\
\mathbf{2} \text { bars } \\
\text { Distance } \\
\mathbf{3 0} \mathbf{~ c m} \\
\text { Deposit speed } \\
\mathbf{1 2} \mathbf{~ m l} / \mathbf{m i n} \\
\text { Deposit time } \\
\mathbf{1 0} \mathbf{~ m i n}\end{array}$} & $450^{\circ} \mathrm{C}$ \\
\hline CISe-2G & & & & $500^{\circ} \mathrm{C}$ \\
\hline CISe-3G & & & & \multirow[b]{2}{*}{$550^{\circ} \mathrm{C}$} \\
\hline CISe-3I & Inox 316 & & & \\
\hline TiN/Ti-1I & \multirow{3}{*}{ Inox 316} & \multirow{3}{*}{ RF Sputtering } & \multirow{3}{*}{$\begin{array}{c}\text { RF power } \\
\mathbf{2 0 0} \mathbf{W} \\
\text { Nitrogen content } \\
\mathbf{5 0} \% \text { vol. } \\
\text { Total pressure } \\
\mathbf{2 0} \mathbf{~ m T o r r} \\
\text { Deposit time } \\
\mathbf{9 0} \text { min }\end{array}$} & $25^{\circ} \mathrm{C}$ \\
\hline TiN/Ti-2I & & & & $500^{\circ} \mathrm{C}$ \\
\hline TiN/Ti-3I & & & & $700^{\circ} \mathrm{C}$ \\
\hline \multirow[b]{2}{*}{ Mo } & Inox 316 & \multirow[b]{2}{*}{ DC Sputtering } & \multirow{2}{*}{\multicolumn{2}{|c|}{$\begin{array}{c}\text { Gas : Argon } \\
\text { Deposit time : } \mathbf{1 8 0} \mathbf{m i n} \\
\text { Substrate temperature: } \mathbf{2 5}^{\circ} \mathbf{C}\end{array}$}} \\
\hline & $\begin{array}{c}\text { TiN/Ti/Inox } \\
316\end{array}$ & & & \\
\hline
\end{tabular}

